\title{
KINERJA BAPEMAS DAN KB KOTA SURABAYA BERDASARKAN ANALISIS PERUBAHAN RENCANA KERJA DAN LAPORAN KINERJA
}

\section{THE PERFORMANCE OF BAPEMAS DAN KB KOTA SURABAYA BASED ON PERFORMANCE PLANNING DOCUMENT ANALYSIS AND PERFORMANCE REPORT}

Deby Indah Permatasari

Fakultas Kesehatan Masyarakat, Universitas Airlangga, Surabaya

E-mail: daybee93@gmail.com

\begin{abstract}
The average population density of Surabaya is 9.002 people per $\mathrm{km}^{2}$ in 2009 . The over population density is potential to occuring problem in health, education, social and economics. To solve that problems, government formed The Empowerment Society and Family Planning(Bapemas dan KB) in Surabaya City. Bapemas dan KB of Surabaya should compute and analyze the performance achievement to attain the optimum performance. This research was to analyse The Performance Achievement based on Performance Planning Document and Performance Planning Amendment compares with Performance Report to solve the performance of workers. This reaserch is observational descriptive research which is held in Sub Area Family Planning Bapemas dan KB Surabaya. The Observation studied The Performance Planning Document and Performance Planning Amendment that compares to Performance Report. The Indepth Interview was in Administrative unit, Head of the Sub-Division, and Head of Division Prosperous Family and Family Planning "Bapemas dan KB" Surabaya. Data Analysis Method using Assesment of Performance Indicators Target that measured by Performance Measurement Form, Self Assesment, and Budget Realization. Performance achievement result were: Family Planning Founding Program was 61,58\%; Contraceptiption Service Provision for Poor Family Program was 97,17\%; in Family Planning Infrastructure Program was 200\%.
\end{abstract}

Keywords:performance, performance report, family planning, program.

\section{PENDAHULUAN}

Penyusunan Rencana Strategis Badan Pemberdayaan Masyarakat dan Keluarga Berencana Kota Surabaya Tahun 2011-2015 yang merupakan tindak lanjut atas ketentuan di dalam Undang-Undang Nomor 25 Tahun 2004 tentang Sistem Perencanaan Pembangunan Nasional yang secara subtansi mempresentasikan Rencana Pembangunan Jangka Menengah Satuan Kerja Perangkat Daerah untuk periode 5 (lima) tahun memiliki strategi untuk memecahkan masalah kesehatan, pendidikan, ekonomi dan masalah sosial yang disebabkan karena kepadatan penduduk di Kota Surabaya sudah sangat memprihatinkan. Jumlah Penduduk Kota Surabaya pada Tahun 2009 sebanyak 2.938.125 jiwa yang terdiri dari 1.474.874 orang laki-laki dan 1.463.351 orang perempuan dengan luas Kota Surabaya $326.37 \mathrm{~km}^{2}$, maka kepadatan penduduk rata-rata mencapai 9.002 jiwa per $\mathrm{km}^{2}$. Dalam melaksanakan program tersebut maka kinerja petugas Bapemas dan KB Kota Surabaya perlu diukur agar mendapatkan hasil yang maksimal.

Rencana Strategis Bapemas dan KB Kota Surabaya dituangkan ke dalam Rencana Kerja Tahunan yang berisikan program-program kegiatan yang akan dilaksanakan. Hasil pelaksanaan Rencana Kerja Tahunan yang telah dilaksanakan akan dimonitor dan dievaluasii dalam Dokumen Laporan Kinerja.

Akuntabilitas Kinerja Instansi Pemerintah merupakan salah satu bentuk media untuk melaporkan keberhasilan atau kegagalan suatu instansi pemerintah atas pelaksanaan tujuan dan 
sasaran organisasi. Akuntabilitas Kinerja didasarkan pada Peraturan Presiden Nomor 29 Tahun 2014 tentang Sistem Akuntabilitas Kinerja Instansi Pemerintah, yang mewajibkan kepada setiap instansi pemerintah melakukan Akuntabilitas Kinerja sebagai bentuk pertanggungjawaban dalam pencapaian tujuan organisasi sesuai tugas pokok dan fungsinya dalam bentuk Laporan Kinerja.

Laporan ini digunakan untuk mempelajari dan menganalisis Pencapaian Kinerja berdasarkan Dokumen Rencana Kerja terhadap Laporan Kinerja Bapemas dan KB Kota Surabaya Tahun 2015.

Laporan ini diharapkan dapat memberikan manfaat bagi pihak yang terkait didalamnya yaitu mahasiswa, perguruan tinggi dan institusi tempat magang. Bagi Mahasiswa diharapkan dapat menimba pelajaran praktis dari lapangan dan membandingkan ilmu yang telah diperoleh dengan pelaksanaan di dunia kerja. Bagi Perguruan Tinggi dalam hal ini adalah Universitas Airlangga dapat memperkaya khasanah dari dunia kerja melalui informasi yang diperoleh dari lapangan. Sehingga dapat melakukan penyesuaian materi perkuliahan terhadap tuntunan dunia kerja yang pada akhirnya dapat menghasilkan sarjana yang lebih kompetitif. Sedangkan, bagi instansi yaitu mahasiswa dapat memberikan ilmu terbaru yang dipelajari dari bangku perkuliahan.

\section{PUSTAKA}

\section{Instansi Pemerintah}

Instansi Pemerintah adalah Perangkat

Negara Kesatuan Republik Indonesia yang menurut peraturan perundangan yang berlaku dan dibiayaioleh Anggaran Negara. (SK LAN No.239/IX/6/8/2003 tentang Pedoman Penyusunan Pelaporan Akuntabilitas Kinerja Instansi Pemerintah).

\section{Perencanaan}

Perencanaan adalah suatu proses menentukan apa yang ingin dicapai di masa yang akan datang serta menetapkan tahapan yang dibutuhkan untuk mencapainya. Proses perencanaan dilakukan dengan menguji berbagai arah pencapaian serta mengkaji berbagai ketidakpastian yang ada, mengukur kemampuan (kapasitas) kita untuk mencapainya kemudian memilih arah-arah terbaik serta memilih langkahlangkah untuk mencapainya.(Rustiadi, 2008)

Adapun syarat perencanaan harus memiliki, mengetahui, dan memperhitungkan: tujuan akhir yang dikehendaki; sasaran dan prioritas untuk mewujudkannya (yang mencerminkan pemilihan dari berbagai alternatif); jangka waktu mencapai sasaran tersebut; masalah yang dihadapi; modal atau sumber daya yang akan digunakan serta pengalokasiannya; kebijakan untuk melaksanakan; orang, organisasi, atau badan pelaksanaannya; mekanisme pemantauan, evaluasi dan pengawasan pelaksaannya.

Kinerja

Kinerja didefinisikan sebagai catatan mengenai outcome yang dihasilkan dari suatu aktivitas tertentu, selama kurun waktu tertentu pula. (Sedarmayanti, 2010) 
Pengukuran Kinerja (Kurja) Instansi Pemerintahan dapat menggunakan metoda pengukuran Performance gap, yaitu membandingkan antara Rencana Kinerja dengan Capaian masing masing Indikator Sasaran maupun Indikator Kinerja Kegiatan (input, outputs, outcomes, benefits, dan impacts).

untuk mengukur kinerja digunakan dua formulir yaitu : Formulir Pengukuran Kinerja Kegiatan (PKK) dan Formulir Pengukuran Pencapaian Sasaran (PPS). Formulir Pengukuran Kinerja Kegiatan (PKK) meliputi pengukuran terhadap indikatorindikator kinerja kegiatan dalam lingkup program yang membawahinya. Pada pengukuran kinerja kegiatan, setiap indikator diukur kinerjanya atas dasar pembandingan antara rencana dan realisasi. Formulir Pengukuran Pencapaian Sasaran (PPS) meliputi pencapaian rencana tingkat capaian (target) untuk setiap indikator sasaran yang telah ditetapkan. Pengukuran pencapaian sasaran dihitung dengan pembandingan rencana dan realisasi untuk setiap indikator yang ditetapkan (Winner, 2008).

Evaluasi Kinerja Instansi Pemerintah dilakukan berdasarkan hasil-hasil perhitungan pada Formulir PKK, untuk mengetahui pencapaian realisasi setiap indikator kinerja kegiatan, kemajuan dan kendala yang dijumpai dalam mencapai visi, misi, agar dapat dinilai dan dipelajari untuk perbaikan dalam pelaksanaan program/ kegiatan yang akan datang. Lebih lanjut dilakukan analisis efisiensi dengan cara membandingkan antara output dengan input baik untuk rencana maupun realisasi, sehingga dapat memberikan gambaran tingkat efisiensi yang dilakukan oleh instansi. Selain itu, dilakukan analisis terhadap pengukuran tingkat efektifitas yang menggambarkan tingkat kesesuaian antara tujuan dengan hasil, manfaat, maupun dampak. Dalam evaluasi ini juga dilakukan analisis terhadap setiap perbedaan kinerja (performance gap) yang terjadi, baik terhadap terjadinya gap baik terhadap terjadinya gap maupun strategi pemecahan masalah yang telah dan akan dilaksanakan (Winner, 2008).

\section{METODE}

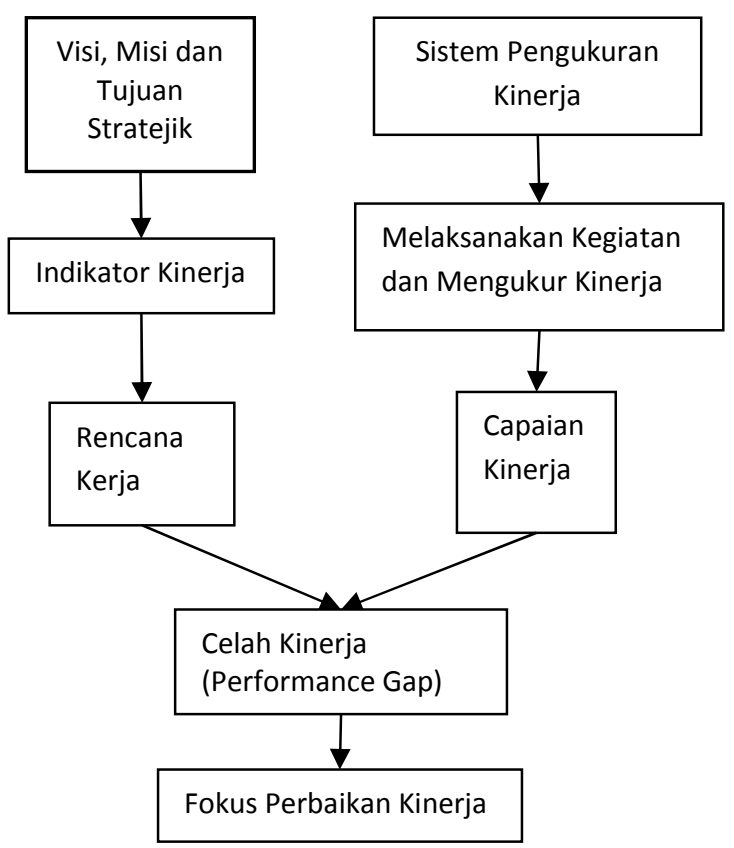

Gambar 1. Kerangka Konseptual Penelitian Sumber: Laporan Akuntabilitas Kinerja Instansi Pemerintah

Penelitian yang dilaksanakan di Sub Bidang Keluarga Berencana Badan Pemberdayaan Masyarakat dan KB Kota Surabaya merupakan kegiatan yang bersifat observasional dan wawancara (Indepth Interview). Observasi dilakukan dengan mempelajari dan 
membandingkan dokumen Rencana Kerja, Perubahan Kerja dan Laporan Kinerja kemudian melihat langsung kondisi yang ada di tempat magang. Kemudian wawancara (Indepth Interview) dilakukan kepada Unit Tata Usaha, Kepala Sub Bidang KB, Kepala Bidang Keluarga Berencana dan Keluarga Sejahtera Badan Pemberdayaan Masyarakat dan Keluarga Berencana Kota Surabaya mengenai pelaksanaan program di instusi tersebut.

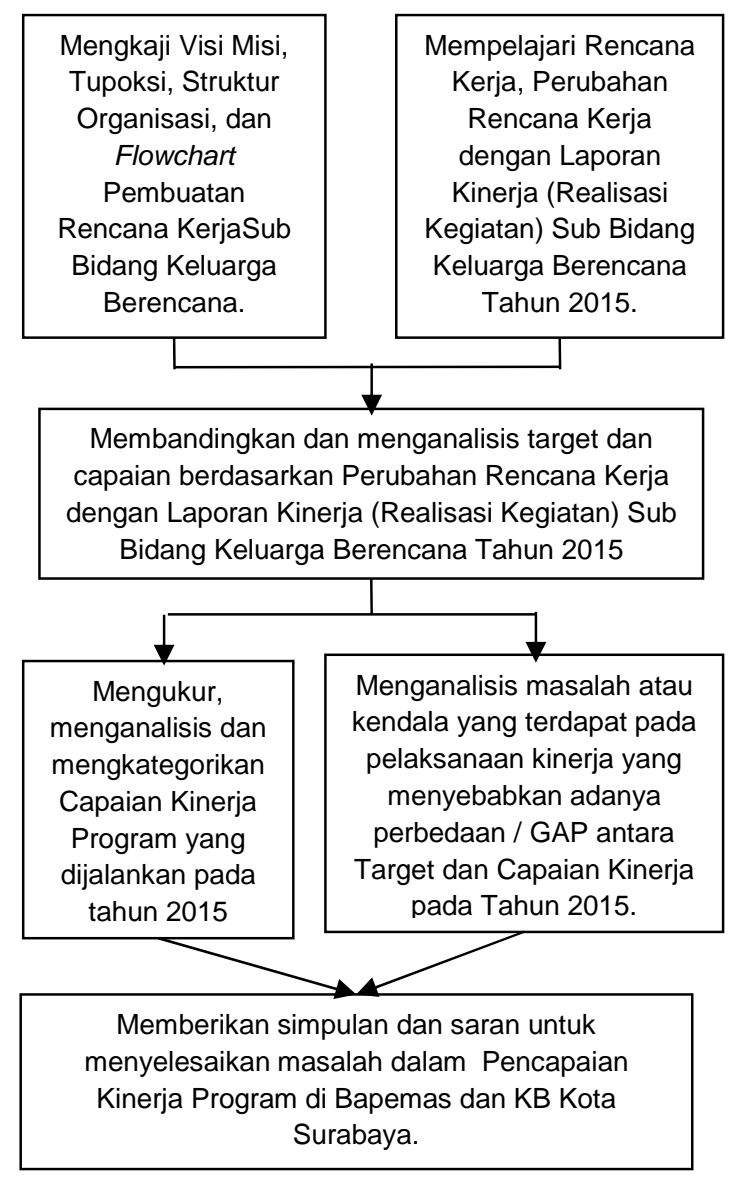

Gambar 2. Kerangka Operasional Penelitian

Penelitian dilakukan tanggal 15 Agustus sampai dengan 9 September 2016 di Bapemas dan KB Kota Surabaya. Subyek yang di teliti adalah Dokumen Rencana Kerja, Perubahan Kerja dan Laporan Kinerja Badan Pemberdayaan Masyarakat
Kota Surabaya Tahun 2015; dan Unit Tata Usaha, Kepala Sub Bidang KB, Kepala Bidang Keluarga Berencana Bapemas dan KB Kota Surabaya.

\section{HASIL DAN PEMBAHASAN}

Visi Bapemas dan KB Kota Surabaya adalah "Keluarga Cerdas dan Berkualitas". Keluarga cerdas dan berkualitas adalah keluarga yang sejahtera, sehat, maju, mandiri, memiliki jumlah anak yang ideal, berwawasan kedepan, bertanggung jawab, harmonis, dan bertaqwa kepada Tuhan Yang Maha Esa.

Sedangkan misi dari Bapemas dan KB Kota Surabaya antara lain: memberdayakan dan menggerakkan masyarakat serta lembaga masyarakat untuk berpartisipasi dalam pembangunan; menggalang kemitraan dalam peningkatan kesejahteraan, kemandirian dan ketahanan keluarga; percepatan pelaksanaan pengarusutamaan gender dalam mewujudkan kesetaraan dan keadilan gender; meningkatkan kualitas SDM SKPD dalam pelaksanaan program.

Berdasarkan wawancara dengan Kepala Bidang Keluarga Berencara dan Keluarga Sejahtera Bapemas dan KB Kota Surabaya, tim yang mensukseskan program kerja Bapemas dan KB Kota Surabaya adalah seluruh petugas. Dengan arahan dan petunjuk dari kepala kemudian dikoordinir tiap bidang sampai ke bagian sub bidang sesuai dengan program kerja di masing-masing sub bidang. Untunk sub bidang KB misalnya, bila ada program maka akan ditunjuk ketua pelaksana yang mengkoordinir jalannya program, kemudian staf dan 
outsourcing menjalankan tugas sesuai dengan bagian masing-masing. Bila program yang dijalankan seperti "Gebrak KB" dan "Kampung KB" maka seluruh pegawai baik outsourcing, staf, Kepala Sub Bidang, Kepala Bidang dan Kepala Badan akan turun langsung ke lapangan menggerakkan masyarakat.

Berikut flowchart Pembuatan Rencana Kerja Bapemas dan KB Kota Surabaya:

\section{Bappeko SKPD Penyelia Admin Dewan}

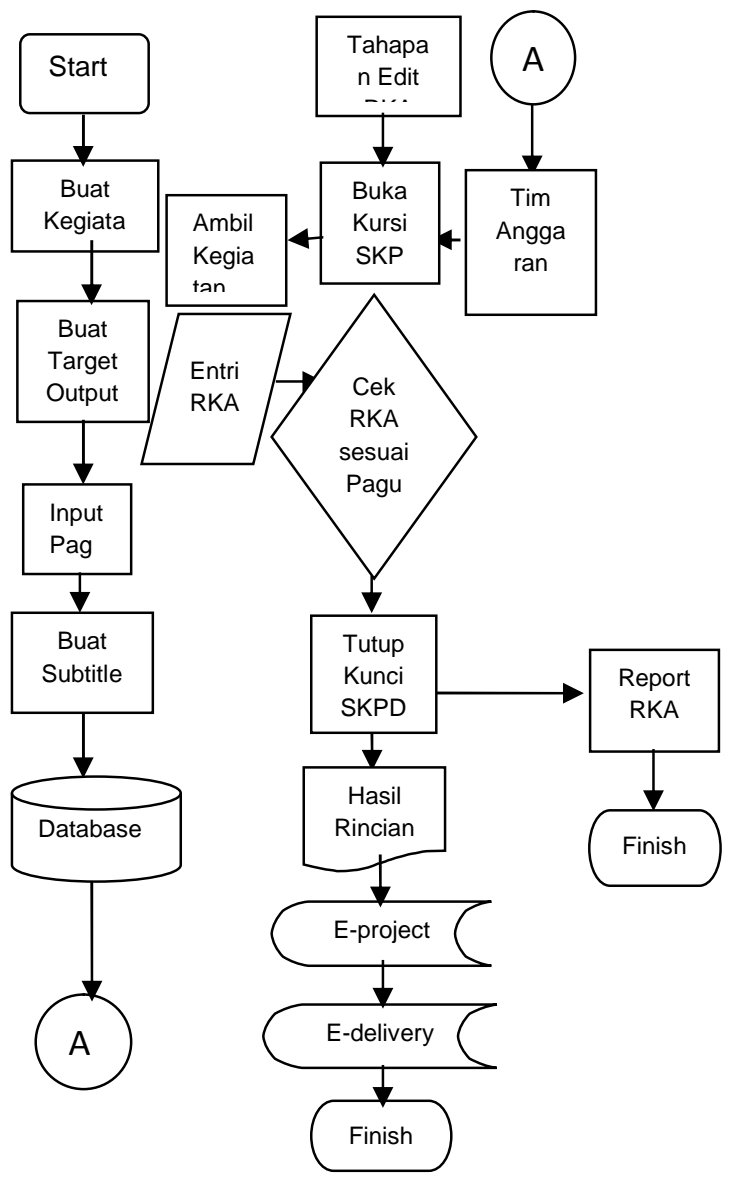

Gambar 3. Flowchart Pembuatan Rencana Kerja Sumber : Bapemas dan KB Kota Surabaya

Berdasarkan wawancara dengan Pegawai Bagian Tata Usaha Badan Pemberdayaan Masyarakat dan KB Kota Surabaya, terdapat perubahan anggaran dari Pemerintah Provinsi (SKPD) sehingga mempengaruhi sedikit target dari program yang telah dibuat sebelumnya dalam
Rencana Kerja Badan Pemberdayaan Masyarakat dan KB Kota Surabaya Tahun 2015. Dari tiga Program yang telah ditentukan dalam Rencana Kerja Tahun 2015, terdapat dua program yang dirubah, namun perubahan tersebut sangat kecil presentasinya dan tidak mempengaruhi kinerja organisasi secara signifikan. Perubahan tersebut terdapat adalah:

Tabel 1. Item dari Perubahan Program Rencana Kerja Tahun 2015 Bapemas dan KB Kota Surabaya

\begin{tabular}{|c|c|c|c|}
\hline PROGRAM & $\begin{array}{c}\text { RENCANA } \\
\text { KERJA }\end{array}$ & $\begin{array}{c}\text { PERUBAHAN } \\
\text { KERJA }\end{array}$ & $\begin{array}{c}\text { PERUBAHAN } \\
\text { PAGU } \\
\text { INDIKATIF }\end{array}$ \\
\hline $\begin{array}{l}\text { Program } \\
\text { Pembinaan } \\
\text { Keluarga } \\
\text { Berencana }\end{array}$ & $\begin{array}{l}5764 \text { orang } \\
\text { Peserta KB } \\
\text { yang dibina }\end{array}$ & $\begin{array}{l}5479 \text { orang } \\
\text { peserta KB } \\
\text { yang dibina }\end{array}$ & -7.195 .471 \\
\hline $\begin{array}{l}\text { Penyediaan } \\
\text { Sarana dan } \\
\text { Prasana } \\
\text { Pelayanan } \\
\text { KB yang } \\
\text { didanai dari } \\
\text { DAK Bidang } \\
\text { KB }\end{array}$ & $\begin{array}{l}5 \text { item } \\
\text { jumlah } \\
\text { sarana dan } \\
\text { prasarana } \\
\text { pelayanan } \\
\text { KB yang } \\
\text { disediakan } \\
\text { dari DAK } \\
\text { Bidang KB }\end{array}$ & $\begin{array}{l}4 \text { item jumlah } \\
\text { sarana dan } \\
\text { prasarana } \\
\text { pelayanan KB } \\
\text { yang } \\
\text { disediakan } \\
\text { dari DAK } \\
\text { Bidang KB }\end{array}$ & -127.428 .902 \\
\hline
\end{tabular}

Dalam menganalisis Pencapaian Kinerja berdasarkan Laporan Kinerja dengan Target Program yang telah ditetapkan dalam Rencana Kerja, maka perlu dilakukan langkah berupa Pembandingan Dokumen Rencana kerja dengan Laporan Hasil Kinerja; Pengukuran Capaian Kinerja; Analisis Capaian Kinerja; Realisasi Anggaran. Pada tahun 2015 di Bapemas dan KB terdapat Perubahan Anggaran yang mengharuskan adanya Perubahan Rencana Kerja, sehingga dokumen tersebut harus dibandingkan antara Target yang terdapat dalam Rencana Kerja dengan Pencapaian dalam Laporan Kinerja. Dari Perbandingan ketiga dokumen tersebut akan terlihat gap atau perbedaan antara Realisasi dengan Rencana yang telah dibuat. Kemudian dari 
gap atau perbedaan tersebut akan dapat diukur seberapa besar Pencapaian Kinerja Per Program. aspek pencapaian program dan seberapa besar penyerapan dana yang telah dianggarkan..

Sehingga program yang telah dibuat dan

dilaksanakan dapat diukur keberhasilannya dari

Tabel 2. Anggaran dan Realisasi Anggaran Badan Pemberdayaan Masyarakat dan Keluarga Berencana Tahun Anggaran 2015 (APBD)

\begin{tabular}{|c|c|c|c|c|}
\hline URAIAN & $\begin{array}{l}\text { ANGGARAN } \\
(\mathrm{Rp})\end{array}$ & $\begin{array}{l}\text { REALISASI } \\
\text { (Rp) }\end{array}$ & $\begin{array}{c}\text { Penyerapan } \\
\text { Anggaran (\%) }\end{array}$ & Ket. \\
\hline \multicolumn{5}{|l|}{ Belanja Langsung } \\
\hline $\begin{array}{l}\text { Program Keluarga } \\
\text { Berencana }\end{array}$ & 3.094.146.569 & 2.445 .249 .110 & 79,03 & $\begin{array}{l}\text { Penghematan sebesar } \\
20,97 \%\end{array}$ \\
\hline $\begin{array}{l}\text { Pembinaan Keluarga } \\
\text { Berencana }\end{array}$ & 493.078 .839 & 430.835 .200 & 87,38 & $\begin{array}{l}\text { Penghematan dana } \\
\text { sebesar } 12,62 \%\end{array}$ \\
\hline $\begin{array}{ll}\text { Penyediaan } & \text { dan } \\
\text { Pelayanan } & \text { Alat } \\
\text { Kontrasepsi } & \text { bagi } \\
\text { Keluarga Miskin } & \\
\end{array}$ & 771.695 .242 & 676.707 .340 & 87,69 & $\begin{array}{l}\text { Penghematan dana } \\
\text { sebesar } 12,31 \%\end{array}$ \\
\hline $\begin{array}{l}\text { Penyediaan Sarana } \\
\text { dan Prasarana } \\
\text { Pelayanan KB yang } \\
\text { disediakan melalui } \\
\text { Dana Alokasi } \\
\text { Bidang KB }\end{array}$ & 637.144 .508 & 171.684 .060 & 26,95 & $\begin{array}{l}\text { Terdapat tambahan Dana } \\
\text { Alokasi Khusus dan } \\
\text { pengadaan sarana } \\
\text { prasarana } 200 \% \text { dengan } \\
\text { serapan sebesar } 26,95 \text { jadi } \\
\text { terdapat penghematan } \\
\text { dana sebesar } 73,05 \%\end{array}$ \\
\hline
\end{tabular}

Tabel 3. Perbandingan Dokumen Rencana Kerja, Perubahan Rencana Kerja dan Laporan Kinerja

\begin{tabular}{|c|c|c|}
\hline $\begin{array}{c}\text { PERUBAHAN } \\
\text { RENCANA KERJA }\end{array}$ & LAPORAN KINERJA & Keterangan \\
\hline $\begin{array}{l}\text { Pembinaan Keluarga } \\
\text { Berencana. Target } \\
\text { Capaian Rencana } \\
\text { Kerja Tahun } 2015 \\
\begin{array}{lr}\text { adalah } & 5.479 \\
\text { orang. }\end{array}\end{array}$ & $\begin{array}{l}\text { Pembinaan Keluarga Berencana } \\
\text { Terdiridaritiga sub kegiatanyaitu: } \\
\text { 1. Gebyar KB dalam rangka Revitalisasi Program KB. } \\
\text { Gebyar KB Tahun } 2015 \text { dilaksanakan Bulan Desember di GOR } \\
\text { Kertajaya/CLS Surabaya diikuti } 2500 \text { orang. } \\
\text { 2. Rakerda Program KB } \\
\text { Berisi pemaparan Kepala Bapemas dan KB Kota Surabaya } \\
\text { tentang hasil yang telah dicapai oleh Bapemas dan KB selama } \\
\text { tahun } 2015 \text {. } \\
\text { 3. Sosialisasi KB Lestari dan KB Pria } \\
\text { Bertujuan memberikan Informasi dan Edukasi kepada masyarakat } \\
\text { Kota Surabaya. }\end{array}$ & $\begin{array}{l}\text { 1. Target5000 } \\
\text { orang, } \\
\text { realisasi } 2500 \\
\text { orang } \\
\text { 2. Sesuai jumlah } \\
\text { target yang } \\
\text { diundang } \\
\text { 3. Target MOP } \\
100 \\
\text { akseptorpria,te } \\
\text { realisasi } 88 \\
\text { orang }\end{array}$ \\
\hline $\begin{array}{l}\text { Penyediaan dan } \\
\text { Pelayanan Alat } \\
\text { kontrasepsi Bagi } \\
\text { Keluarga Miskin } \\
\text { Target Capaian } \\
\text { Renja Tahun 2015 } \\
\text { adalah 424 orang. }\end{array}$ & $\begin{array}{l}\text { Penyediaan dan Pelayanan Alkon Bagi Gakin } \\
\text { Untuk mengendalikan Laju Pertambahan Penduduk, dilakukan } \\
\text { upaya pegaturan kelahiran melalui metode Medis Operasi Pria } \\
\text { (MOP) dan Metode Operasi Wanita (MOW). Untuk tahun } \\
\text { 2015, MOP telah dilayani sebanyak } 88 \text { akseptor sedangkan } \\
\text { untuk MOW } 324 \text { akseptor. }\end{array}$ & $\begin{array}{l}\text { Target } 424 \text { orang } \\
\text { Realisasi } \\
\text { orang }\end{array}$ \\
\hline $\begin{array}{l}\text { Penyediaan Sarana } \\
\text { dan Prasarana } \\
\text { Pelayanan KB yang } \\
\text { Didanai dari DAK } \\
\text { Bidang KB } \\
\text { 1. Target Capaian } \\
\text { Renja Tahun } 2015 \\
\text { adalah } 4 \text { item. } \\
\text { 2. Operasional } \\
\text { Pendampingan } \\
\text { DAK Bidang KB. }\end{array}$ & $\begin{array}{l}\text { Penyediaan Sarana dan Prasarana Pelayanan KB yang Didanai } \\
\text { dari DAK Bidang KB } \\
\text { 1. DAK Bidang Keluarga Berencana } \\
\text { Dana Alokasi Khusus yaitu dana yang diperoleh dari Pemerintah } \\
\text { Pusat dalam hal ini BKKBN untuk dibelanjakan sesuai petunjuk } \\
\text { teknis. DAK Bidang KB sebesar Rp. } 637.144 .508 \text { untuk } \\
\text { pembelian } 2 \text { unit printer, } 4 \text { unit Note Book i7, } 2 \text { unit LCD } \\
\text { Proyektor. } \\
\text { 2. Operasional Pendampingan DAK Bidang Keluarga Berencana } \\
\text { Pengadaan ATK, pengadaan server untuk menunjang program } \\
\text { pendataan keluarga dan kebutuhan lainnya }\end{array}$ & $\begin{array}{l}\text { Terdapat } \\
\text { tambahan Dana } \\
\text { Alokasi Khusus } \\
\text { dari pemerintah } \\
\text { provinsi, } \\
\text { sehingga } \\
\text { pencapaian } 8 \\
\text { item dari target } 4 \\
\text { item }\end{array}$ \\
\hline
\end{tabular}


Pengukuran kinerja menggunakan Penilaian Indikator Kinerja Sasaran yang diukur dengan Formulir Pengukuran Kinerja (Form. PK) berdasarkan Teori Laporan Akuntabilitas Kinerja Instansi Pemerintah (LAKIP).

Penghitungan Persentase Pencapaian

Rencana Tingkat Capaian (Formulir Pengukuran Kinerja), menggunakan rumus :

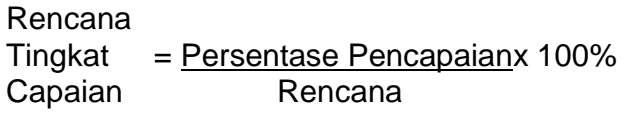

Hasil Penghitungan Persentase Pencapaian Rencana Tingkat Capaian (Formulir Pengukuran Kinerja) adalah sebaga berikut :

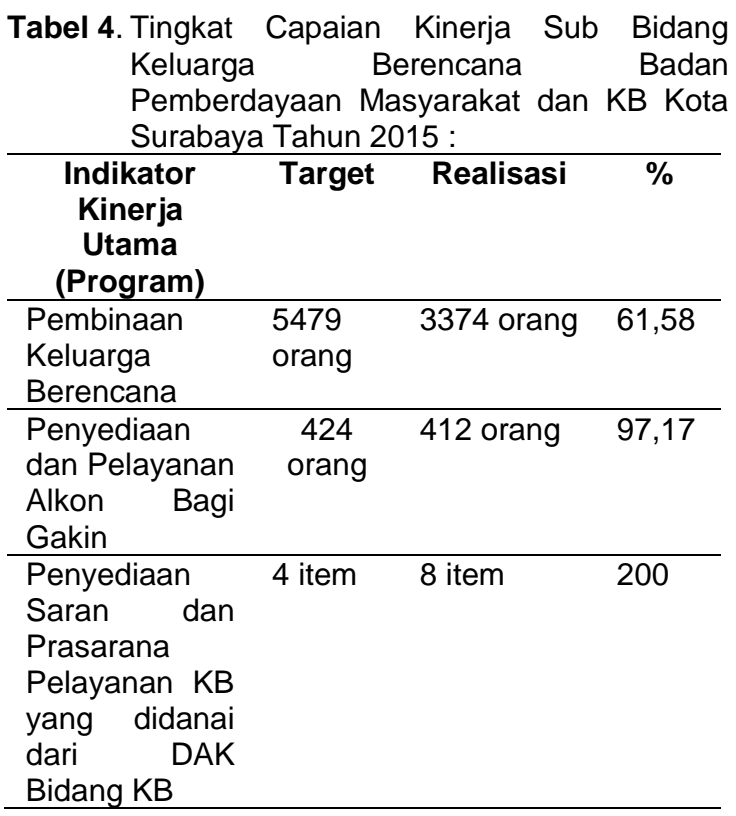

Tabel 5. Kategori Pencapaian Kinerja (Self

\begin{tabular}{ll}
\multicolumn{2}{c}{ Assessment) } \\
\hline $\begin{array}{c}\text { Rentang Capaian } \\
\text { Kinerja }\end{array}$ & \multicolumn{1}{c}{$\begin{array}{c}\text { Kategori Capaian } \\
\text { Kinerja }\end{array}$} \\
\hline$\geq 100 \%$ & Memuaskan \\
$85 \%-100 \%$ & Sangat Baik \\
$70 \%-84,99 \%$ & Baik \\
$55 \%-69,99 \%$ & Sedang \\
$<55 \%$ & Kurang Baik \\
\hline
\end{tabular}

Analisis capaian kinerja masing-masing program diuraikan menurut indicator kinerja dari kegiatan yang dilaksanakan. Dari uraian tersebut di atas, maka gambaran evaluasi dan analisis kinerja hasil pengukuran kinerja sasaran stratejik antara lain untuk Program Pembinaan Keluarga Berencana, dari target Rencana Kerja sebanyak 5479 orang peserta KB yang dibina, hanya dapat terealisasi sebanyak 3374 orang. Sehingga persentase capaian kinerjanya sebanyak $61,58 \%$. Sehingga berdasarkan Rentang Capaian Kinerja (self assessment) diatas, maka Program Pembinaan Keluarga Berencana terdapat pada kategori "Sedang".

Untuk Program Penyediaan Alat Kontrasepsi bagi Gakin hanya tercapai $97,17 \%$. Pencapaian tersebut hampir mendekati $100 \%$ namun tedapat kendala kurangnya kepesertaan KB MOP sehingga target $100 \%$ tersebut tidak dapat dicapai. Sehingga berdasarkan Rentang Capaian Kinerja (Self Assessment) diatas, maka Program Penyediaan Alat Kontrasepsi bagi Gakin terdapat pada kategori "Sangat Baik".

Sedangkan untuk Program Penyediaan Saran dan Prasarana Pelayanan KB yang didanai dari DAK Bidang KB berhasil mencapai persentase capaian kinerja sebanyak 200\%. Dana Alokasi Khusus yaitu dana yang diperoleh dari Pemerintah Pusat dalam hal ini BKKBN untuk dibelanjakan sesuai petunjuk teknis yang ada. Tahun 2015 Bapemas dan KB memperoleh dana DAK Bidang Keluarga Berencana sebesar Rp. 637.144.508 yang dibelanjakan untuk keperluan pembelian 2 unit printer, 4 unit Note Book i7, 10 unit sound system (Wireless Public Address), 2 unit LCD Proyektor. Sehingga berdasarkan Rentang Capaian Kinerja 
(Self Assessment) diatas, maka Program Penyediaan Saran dan Prasarana Pelayanan KB yang didanai dari DAK Bidang KB terdapat pada kategori "Memuaskan”.

Semua dana yang tersisa, akan dikembalikan lagi ke Pemerintah Kota Surabaya. Dan untuk program kerja tahun selanjutnya, akan diberikan dana lagi.

Dari wawancara dengan Kepala Sub Bidang Keluarga Berencana Badan Pemberdayaan Masyarakat dan KB Kota Surabaya, dalam pelaksanaan program yang telah disepakati dalam Rencana Kerja tahun 2015 terdapat kendala yang meliputi segi administrasi, segi target dan segi waktu.

Dari segi administratif, karena setiap pelaksanaan program harus di SPJ-kan maka untuk pelaksanaannya, dalam hal pelayanan KB MOW misalnya, tidak semua peserta KB MOW tersebut memiliki persyaratan administratif yang telah ditentukan. Misalnya KTP yang seharusnya bertempat tinggal di wilayah Surabaya, maka tidak semua peserta tersebut adalah asli penduduk Surabaya. Kemudian Surat Nikah yang tidak semua peserta KB memiliki karena ada beberapa peserta tersebut yang menikah siri. Untuk penyelesaiannya, memakai KTP Sementara, walaupun sebenarnya hal tersebut tidak diperbolehkan. Kendala eksternal tersebut disebabkan karena kurangnya kesadaran masyarakat terhadap pentingnya KTP.

Untuk segi target, khususnya target MOP yang hanya tercapai 88 dari target sebanyak 100 . Faktor masih ada beberapa masyarakat laki-laki tidak mau MOP padahal secara usia dan syarat lainnya telah terpenuhi. Padahal pemerintah sendiri telah melakukan berbagai upaya menarik minat masyarakat laki-laki untuk melakukan MOP seperti pemberian imbalan berupa sepeda gunung, uang sebesar RP 1.000.000,- dan juga berbagai promosi, sosialisasi yang gencar, grebek $\mathrm{KB}$, kampung $\mathrm{KB}$ untuk menarik minat peserta MOP lainnya. Namun, pada saat melakukan pengambilan keputusan pada diri peserta tersebutlah yang sulit untuk dirubah.

Sedangkan dari segi waktu, ada beberapa program yang misalnya pada semester I target harus segera tercapai, namun ternyata terdapat program yang baru turun dari provinsi atau pusat. Sehingga pelaksanaan program tersebut terpaksa molor.

\section{SIMPULAN}

Berdasarkan Persentase Pencapaian Kinerja tersebut diatas, Kinerja Sub Bidang Keluarga pada Program Pembinaan Keluarga Berencana pencapaian kinerjanya sebanyak $61,58 \%$ masuk dalam kategori "Sedang" dengan penyerapan anggaran sebesar $87,38 \%$ sehingga terdapat penghematan dana sebesar $12,62 \%$

Pada Program Penyediaan dan Pelayanan Alkon bagi Gakin persentase pencapaiannya kinerjanya sebanyak $97,17 \%$ termasuk dalam kategori "Sangat Baik" dengan penyerapan anggaran sebesar $87,69 \%$ sehingga terdapat penghematan dana sebesar $12,31 \%$.

Sedangkan untuk Program Penyediaan Saran dan Prasarana Pelayanan KB yang didanai 
dari DAK Bidang KB berhasil mencapai persentase capaian kinerja sebanyak $200 \%$. Sehingga masuk pada kategori "Memuaskan" dengan penyerapan anggaran sebesar $26,95 \%$ sehingga terdapat penghematan dana sebesar $73,05 \%$.

Dalam melakukan pelaksanaan kinerja yang telah tertuang dalam Rencana Kerja banyak kendala yang menghambat Pencapaian Kinerja Sub Bidang Keluarga Berencana di Badan Pemberdayaan Masyarakat dan KB Kota Surabaya. Saran dari penulis dalam menghadapi kendala tersebut antara lain dari segi administratif, segi target dan segi waktu.

Dari segi administrasi, penyebab dari masalah ini berkaitan dengan masyarakat atau faktor eksternal dari Rencana Kerja yang telah disusun Badan Pemberdayaan Masyarakat maka untuk mengatasi hal tersebut berdasarkan teori perlu dilakukan penyelesaian masalah berdasarkan segi administrasi yaitu dengan menyebarkan brosur, pamflet, poster, flyer yang berisikan tentang rincian program kegiatan secara singkat padat dan jelas seperti tentang syarat dan ketentuan dalam mengikuti program kegiatan tersebut. Sehingga masyarakat sasaran dapat dengan jelas mengerti tentang kegiatan yang akan dijalankan dan mempersiapkan persyaratan administrasi yang dibutuhkan. Hal ini dilakukan untuk meminimalisir permasalahan dari segi persyaratan administrasi yang terjadi pada masyarakat sasaran.

Target sasaran program yang telah dibuat adalah masyarakat. Upaya merubah perilaku masyarakat harus melalui beberapa tahapan dan proses yang tidak instan. Agar perubahan perilaku tersebut lebih efektif, maka instansi perlu mengetahui dulu sumber penyebab permasalahan mengapa target MOP tidak berhasil seperti target dari program yang lainnya. Karena proses pengambilan keputusan tindakan MOP sepenuhnya berada di tangan masyarakat, maka perlu diselidiki dahulu tentang apa saja faktor yang mempengaruhi pengambilan keputusan tersebut. Bila dalam masyarakat lebih berpaku pada stigma sebagai contoh laki-laki yang MOP dianggap tidak bisa memiliki anak atau mandul atau tidak subur. Maka instansi perlu mengubah stigma tersebut agar memiliki sudut pandang baru dari masyarakat. Misalnya, "Sayang Istri, Suami ber-KB" sehingga dapat mengubah pandangan masyarakat bahwa suami memiliki tanggung jawab dalam kesehatan reproduksi istrinya. Istri yang telah berperan dalam hamil, melahirkan, menyusui kemudian peran berKB diambil oleh suami sebagai wujud kasih sayang dan perhatian dalam kesehatan reproduksi istrinya.

Sedangkan kendala dari segi waktu, yaitu pelaksanaan program tidak sesuai dengan perencanaan dalam Rencana Kerja. Hal ini disebabkan banyaknya program yang harus dilaksanakan kemudian pemerintah pusat menurunkan program baru dan pemerintah pusat belum meturunkan petunjuk teknis pelaksaan program yang akan segera dilaksanakan. Maka saran penulis dalam hal ini adalah untuk meningkatkan hubungan dan koordinasi yang lebih dekat lagi antara instansi Bapemas dan KB dengan lembaga yang lebih tinggi di atasnya. Dengan 
meningkatkan hubungan yang baik dan lebih erat, maka instansi Bapemas dan KB akan lebih update tentang issu-issu program yang akan digulirkan sehingga dapat mempersiapkan diri mengantisipasi bila issu program tersebut diturunkan. Karena instansi telah mempersiapkan diri sebelumnya, maka pelaksanaan program pun dapat dijadwalkan lagi dengan rapi.

\section{DAFTAR PUSTAKA}

Bapemas dan KB Kota Surabaya. (2015). Rencana Kerja Badan Pemberdayaan Masyarakat dan KB Kota Surabaya Tahun 2015. Bapemas dan KB : Surabaya

Bapemas dan KB Kota Surabaya. (2015). Perubahan Rencana Kerja Badan Pemberdayaan Masyarakat dan KB Kota Surabaya Tahun 2015. Bapemas dan KB : Surabaya

Bapemas dan KB Kota Surabaya. (2015). Laporan Kinerja Badan Pemberdayaan Masyarakat dan
KB Kota Surabaya Tahun 2015. Bapemas dan KB : Surabaya.

Dinas Tenaga Kerja dan Transmigrasi Provinsi Jawa Timur. Laporan Akuntabilitas Kinerja Instansi Pemerintah (LAKIP) Tahun 2013. (2013). Dinas Tenaga Kerja dan Transmigrasi Provinsi Jawa Timur : Surabaya.

Lembaga Administrasi Negara Republik Indonesia (2003), Keputusan Kepala Lembaga Administrasi Negara No. 239/IX/6/8/2003 tentang Perbaikan Pedoman Penyusunan Pelaporan Akuntabilitas Kinerja Instansi Pemerintah.

Peraturan Presiden Nomor 29 Tahun 2014 Tentang Sistem Akuntabilitas Kinerja Instansi Pemerintah.

Rustiadi, Ernan. (2008). Perencanaan dan Pengembangan Wilayah, edisi Mei 2006., Fakultas Pertanian IPB : Bogor.

Sedarmayanti. (2010). Sumber Daya Manusia dan Produktivitas Kerja. Bandung : CV Maju

Undang-Undang Nomor 25 Tahun 2004 tentang Sistem Perencanaan Pembangunan Nasional.

Winner J.A. (2008). Akuntabilitas Keuangan dan Kinerja : Pengertia, Sejarah dan aplikasinya pada Instansi Pemerintah. Studi Kasus : Direktorat Pembinaan SMK.Tesis. Program Studi Magister Ekonomi Fakultas Ekonomi Universitas Indonesia. 